Prepared in cooperation with the U.S. Department of Energy, National Nuclear Security Administration, Nevada Site Office, under Interagency Agreement, DE-Al52-07NA28100, Bureau of Land Management, National Park Service, and Nye County

\title{
Update to the Ground-Water Withdrawals Database for the Death Valley Regional Ground-Water Flow System, Nevada and California, 1913-2003
}

Data Series 340 



\section{Update to the Ground-Water Withdrawals Database for the Death Valley Regional Ground-Water Flow System, Nevada and California, 1913-2003}

By Michael T. Moreo and Leigh Justet

Prepared in cooperation with the U.S. Department of Energy, National Nuclear Security Administration, Nevada Site Office, under Interagency Agreement, DE-Al52-07NA28100, Bureau of Land Management, National Park Service, and Nye County

Data Series 340 


\section{U.S. Department of the Interior DIRK KEMPTHORNE, Secretary}

\section{U.S. Geological Survey \\ Mark D. Myers, Director}

\section{U.S. Geological Survey, Reston, Virginia: 2008}

For product and ordering information:

World Wide Web: http://www.usgs.gov/pubprod

Telephone: 1-888-ASK-USGS

For more information on the USGS--the Federal source for science about the Earth, its natural and living resources, natural hazards, and the environment:

World Wide Web: http://www.usgs.gov

Telephone: 1-888-ASK-USGS

Any use of trade, product, or firm names is for descriptive purposes only and does not imply endorsement by the U.S. Government.

Although this report is in the public domain, permission must be secured from the individual copyright owners to reproduce any copyrighted materials contained within this report.

Suggested citation:

Moreo, M.T., and Justet, Leigh, 2008, Update to the ground-water withdrawals database for the Death Valley regional ground-water flow system, Nevada and California, 1913-2003: U.S. Geological Survey Data Series 340, 10 p. 


\section{Contents}

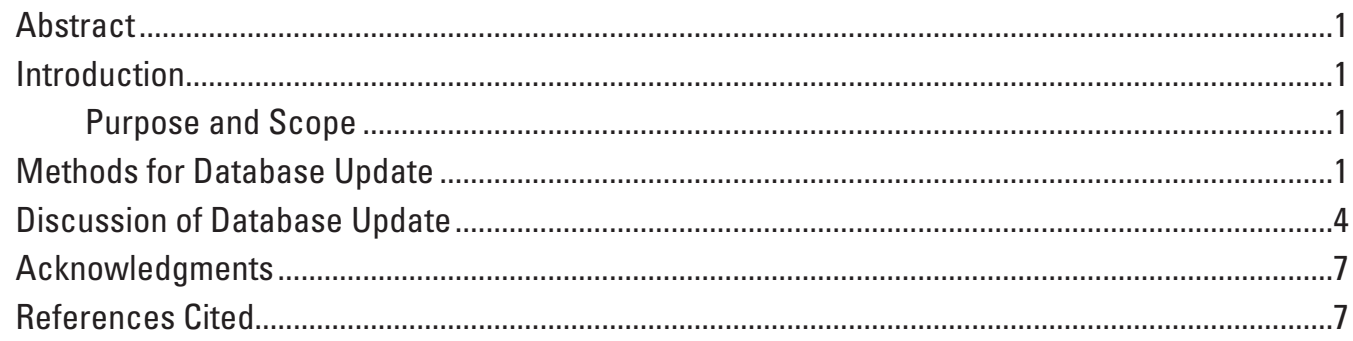

Appendix A. Ground-Water Withdrawal Data for the Death Valley Regional Ground-Water Flow System, 1913-2003.

\section{Figures}

Figure 1. Map showing boundaries of Death Valley regional ground-water flow system model, Nevada Test Site, and hydrographic areas, Nevada and California

Figure 2. Graph showing total ground-water withdrawals by water-use class in the Death Valley regional ground-water flow system model area, Nevada and California, 1913-2003....

Figure 3. Graphs showing ground-water withdrawals for significant water-use classes for selected hydrographic areas and Nevada Test Site, Death Valley regional ground-water flow system, Nevada and California, 1994-2003

\section{Tables}

Table 1. Estimated application rates for high-water-use crops by hydrographic area from the original database and revised application rates developed for the updated database, Death Valley regional ground-water flow system, Nevada and California 


\section{Conversion Factors and Datums}

Conversion Factors

\begin{tabular}{lcl}
\hline Multiply & By & To obtain \\
\hline \multicolumn{3}{l}{ Length } \\
\hline foot (ft) & 0.3048 & meter $(\mathrm{m})$ \\
\hline acre & Area & \\
acre & 0.4047 & hectare $(\mathrm{ha})$ \\
acre & 43,560 & square foot $\left(\mathrm{ft}^{2}\right)$ \\
& 4,047 & square meter $\left(\mathrm{m}^{2}\right)$ \\
\hline acre-foot (acre-ft) & Volume & \\
acre-foot (acre-ft) & 1,233 & cubic meter $\left(\mathrm{m}^{3}\right)$ \\
million gallons (Mgal) & 0.325851 & million gallons $(\mathrm{Mgal})$ \\
million gallons (Mgal) & 3,785 & cubic meters $\left(\mathrm{m}^{3}\right)$ \\
& 3,785 & million liters $(\mathrm{Mliters})$ \\
\hline acre-foot per year (acre-ft/yr) & Volumetric Rate & \\
million gallons per year (Mgal/yr) & 1,233 & cubic meter per year $\left(\mathrm{m}^{3} / \mathrm{yr}\right)$ \\
\hline
\end{tabular}

Datums

Vertical coordinate information is referenced to the National Geodetic Vertical Datum of 1929 (NGVD 29).

Horizontal coordinate information is referenced to the North American Datum of 1927 (NAD 27).

Altitude, as used in this report, refers to distance above the vertical datum. 


\title{
Update to the Ground-Water Withdrawals Database for the Death Valley Regional Ground-Water Flow System, Nevada and California, 1913-2003
}

\author{
By Michael T. Moreo and Leigh Justet
}

\begin{abstract}
Ground-water withdrawal estimates from 1913 through 2003 for the Death Valley regional ground-water flow system are compiled in an electronic database to support a regional, three-dimensional, transient ground-water flow model. This database updates a previously published database that compiled estimates of ground-water withdrawals for 1913-1998. The same methodology is used to construct each database. Primary differences between the 2 databases are an additional 5 years of ground-water withdrawal data, well locations in the updated database are restricted to Death Valley regional ground-water flow system model boundary, and application rates are from 0 to 1.5 feet per year lower than original estimates. The lower application rates result from revised estimates of crop consumptive use, which are based on updated estimates of potential evapotranspiration. In 2003, about 55,700 acre-feet of ground water was pumped in the DVRFS, of which 69 percent was used for irrigation, 13 percent for domestic, and 18 percent for public supply, commercial, and mining activities.
\end{abstract}

\section{Introduction}

The U.S. Geological Survey (USGS), in cooperation with the Department of Energy, developed a transient ground-water flow model of the Death Valley region of southern Nevada and southeastern California to evaluate the effects of Nevada Test Site (NTS) activities on the regional ground-water flow system (Belcher and others, 2004; fig. 1). A database of spatially and temporally distributed ground-water withdrawals was developed to provide input datasets for modeling this large and complex ground-water flow system (San Juan and others, 2004). The previously published database documented the history of ground-water withdrawals in the Death Valley regional ground-water flow system (DVRFS) by user and water-use category from 1913 to 1998 (Moreo and others, 2003). Refining the ground-water flow model required extending the database through 2003 and improving water-use estimates.

\section{Purpose and Scope}

This report documents updates to the original groundwater withdrawals database for the DVRFS ground-water flow model. Annual ground-water withdrawal estimates from 1913 to 2003 for each identified withdrawal location are compiled in an electronic database that is included in this report. Three revisions were made to the database. First, the updated database extends annual ground-water withdrawal estimates from 1998 through 2003 by using the same methodology described by Moreo and others (2003). Second, the updated database includes only data for withdrawal locations within the DVRFS model boundary as defined by Belcher and others (2004). Third, the ground-water withdrawal for irrigation was recomputed using improved estimates of crop consumptive use.

\section{Methods for Database Update}

Similar to the previously constructed database, this database integrates datasets obtained from multiple sources: (1) well-log and water-rights databases and pumpage inventories from the Nevada Division of Water Resources (NDWR), (2) data obtained directly from water users, (3) remotely sensed Thematic Mapper (TM) imagery, and (4) estimates of potential evapotranspiration (PET). Together, these datasets are used to develop reasonable estimates of annual ground-water withdrawal from known and approximate well locations (Moreo and others, 2003).

Subsequent to the completion of the previous database, a newer more accurate PET dataset was developed by Flint and Flint (2007) for use in their Basin Characterization Model (BCM). The Flint and Flint (2007) PET dataset was computed using the Priestley-Taylor equation, and compares well to measured rates from 204 weather sites operated by the California Irrigation Management Information System (CIMIS; http://wwwcimis.water.ca.gov) and 26 weather sites operated in Arizona by the Arizona Meteorological Network (AZMET; http://ag.arizona.edu/azmet/). The CIMIS and 


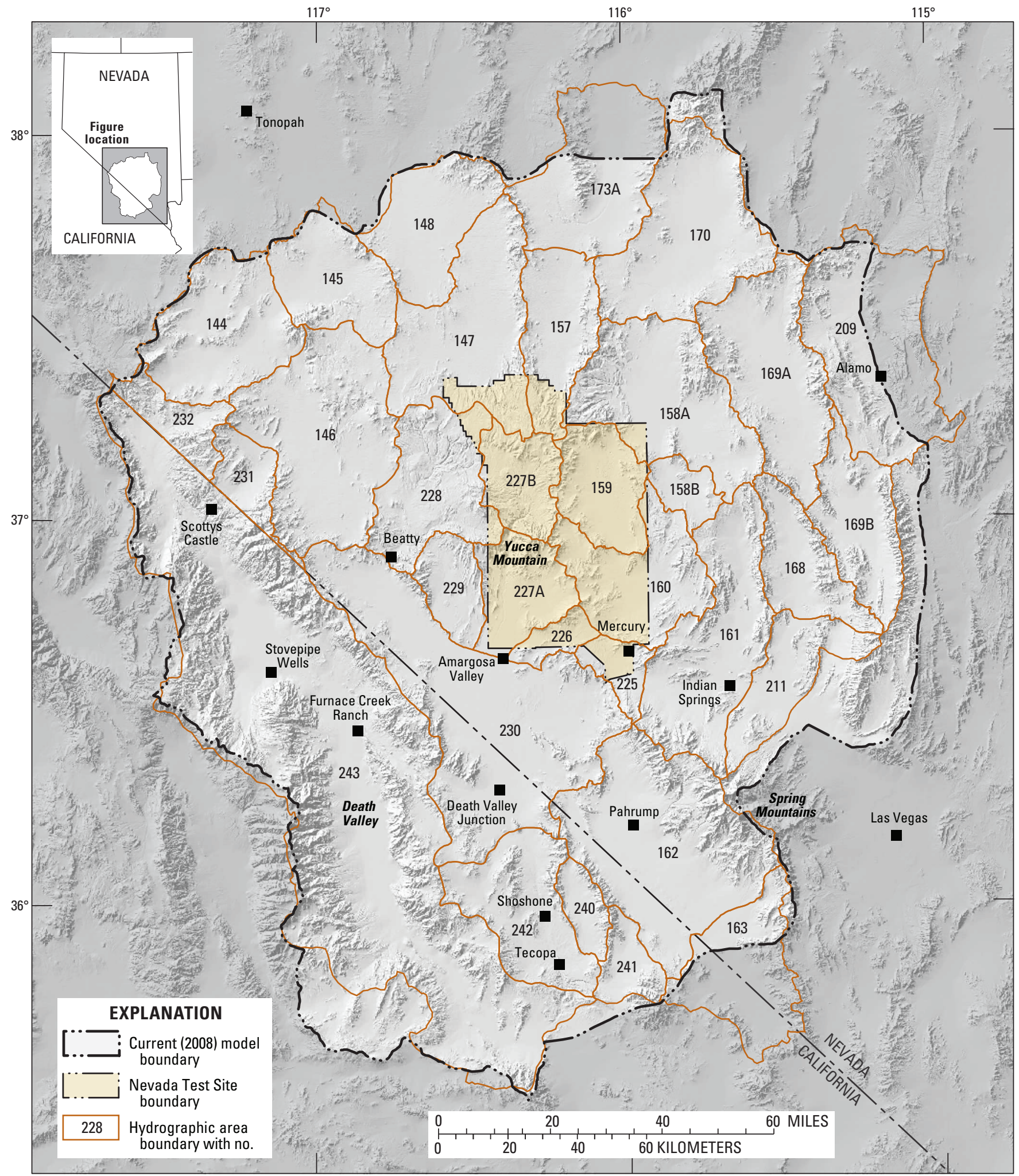

Figure 1. Boundaries of Death Valley regional ground-water flow system model, Nevada Test Site, and hydrographic areas, Nevada and California. 
AZMET networks use the standardized Penman-Monteith reference ET equation (ET ) to calculate PET (Allen and others, 2005). Crop consumptive use, referred to here as crop evapotranspiration $\left(E T_{c}\right)$, is the product of $E T_{o}$ and a crop coefficient $\left(K_{c}\right)$ (U.S. Department of Agriculture, 1993):

$$
E T_{c}=E T_{o} * K_{c},
$$

where

$E T_{c}$ is annual crop evapotranspiration, in feet per year;

$E T_{o}$ is reference evapotranspiration, in feet per year, and

$K_{c}$ is the crop coefficient, dimensionless.

PET computed by Flint and Flint (2007) is considered a reasonable surrogate for $E T_{o}$. A network similar to CIMIS does not exist to estimate $E T_{o}$ in Nevada, thus PET computed by Flint and Flint (2007) is the best available substitute. The advantages of using $E T_{o}$ for the present study are: (1) $E T_{o}$ is thought to be more accurate for estimating water use by irrigated agriculture than the previously applied PET estimates (Shevnell, 1996), and is gaining acceptance as the benchmark equation used by the agricultural community (Allen and others, 2005), and (2) $K_{c}$ values developed by CIMIS are transferable (Allen and others, 2005), and as a result can be used to estimate $E T_{c}$ in Nevada.

High-water-use crops (primarily alfalfa) accounted for about 95 percent of irrigated acreage from 1999 to 2003. ET for high-water-use crops was computed as the product of $E T_{o}^{c}$ and the average growing season $K_{c}$ value of 1 developed by CIMIS for alfalfa. The difference between revised and original $E T_{c}$ estimates for high-water-use crops ranged from -0.9 to $+0.3 \mathrm{ft} / \mathrm{yr}$ (table 1).
The rate at which water is applied by an irrigation system to a crop during a growing season is referred to as the application rate $(A R)$. $A R$ estimates for high-water-use crops based on the revised $E T_{c}$ rates were from 0 to $1.5 \mathrm{ft} / \mathrm{yr}$ lower than original estimates (table 1). $A R$ estimates for high-wateruse crops in the original and updated databases were based on the following equation (Moreo and others, 2003):

$$
A R=E T_{c} / E f f
$$

where

$A R$ is application rate, in feet per year; and

Eff is irrigation efficiency, dimensionless.

Irrigation efficiency (Eff) is the ratio of water beneficially used by a crop to ground water pumped during an irrigation season. Values of Eff were unchanged from those used by Moreo and others (2003); therefore, lower application rate estimates for high-water-use crops in Pahrump Valley and Amargosa Desert were based on lower $E T_{c}$ estimates. The method used to estimate $A R$ for low-water-use crops was unchanged from the original database (Moreo and others, 2003).

The range in $A R$ uncertainty for high-water-use crops in this database (table 1) is narrower to reflect a more reasonable minimum and maximum for model simulations than the range in the previous database (table 1). The uncertainty range in the original database assumed extreme irrigation system efficiencies during the shortest and longest possible growing season (Moreo and others, 2003). The revised $A R$ uncertainty range was based on interviews with local farmers in Pahrump Valley and Amargosa Desert, and on limited metered or measured withdrawals reported in NDWR pumpage inventories from 1959 to 2003.

Table 1. Estimated application rates for high-water-use crops by hydrographic area from the original database and revised application rates developed for the updated database, Death Valley regional ground-water flow system, Nevada and California.

[Application rate: Calculated using equation 2 in text. Most likely application rate determined using crop coefficient $=1.0$ and irrigation efficiency $=0.75$ (except HA 162 = 0.65). Original database: Potential ET estimated from Shevenell (1996). Updated database: Potential ET estimated from Flint and Flint

\begin{tabular}{|c|c|c|c|c|c|c|c|c|c|c|c|}
\hline \multirow{2}{*}{\multicolumn{2}{|c|}{ Hydrographic area }} & \multicolumn{5}{|c|}{$\begin{array}{c}\text { Original database } \\
\text { (Moreo and others, 2003) }\end{array}$} & \multicolumn{5}{|c|}{$\begin{array}{l}\text { Updated database } \\
\text { (This report) }\end{array}$} \\
\hline & & \multicolumn{2}{|c|}{ ET (ft/yr) } & \multicolumn{3}{|c|}{ Application rate (ft/yr) } & \multicolumn{2}{|c|}{ ET (ft/yr) } & \multicolumn{3}{|c|}{ Application rate (ft/yr) } \\
\hline 162 & Pahrump Valley & 6.4 & 5.9 & 5 & 9 & 14 & 5.0 & 5.0 & 5 & 7.5 & 10 \\
\hline 170 & Penoyer Valley & 3.8 & 3.5 & 3 & 5 & 7 & 3.8 & 3.8 & 4 & 5 & 6 \\
\hline
\end{tabular}
(2007). A bbreviations: ET, evapotranspiration; ft/yr, foot per year] 


\section{Discussion of Database Update}

The major differences within the DVRFS model boundary between the previous and updated databases are that (1) estimated $A R$ for high-water-use crops were based on new estimates of crop consumptive use and (2) the updated database extends ground-water withdrawal estimates through 2003. The updated database still shows the same overall spatial and temporal trends. In the three hydrographic areas with significant irrigation, the "likely" $A R$ estimates for high-water-use crops are $1.5 \mathrm{ft} / \mathrm{yr}$ lower in Pahrump Valley, identical in Sand Spring Valley (known locally as Penoyer Valley), and $1 \mathrm{ft} / \mathrm{yr}$ lower in the Amargosa Desert (table 1). An overall decrease in the irrigation water use estimate results from adjusting the application rate. Estimates between the previous and updated databases decreased by 0 to 7 percent before 1978, and by 8 to 13 percent from 1979 to 1998 . For example, the irrigation water use in 1998 decreased by about 13 percent from the previous estimate $(60,500 \mathrm{acre}-\mathrm{ft})$ to the updated estimate (52,800 acre-ft). Prior to 1979 estimates more heavily relied on literature values rather than on the crop coefficient method and thus were not influenced as significantly by the current evaluation (Moreo and others, 2003).

In the extended time frame of the updated database, the total ground-water withdrawal decreased from a maximum of about 69,800 acre-ft in 1998 to 62,900 acre-ft in 1999 to
55,500 acre-ft in 2000; from 2001 to 2003, the total groundwater withdrawal remained relatively constant. In 2003, about 55,700 acre-ft of ground water was pumped in the DVRFS, of which 69 percent was used for irrigation, 13 percent for domestic, and 18 percent for public supply, commercial, and mining activities (fig. 2).

Between 1998 and 2003 total ground-water withdrawal from Pahrump Valley decreased by 10,000 acre-ft, irrigation use decreased by 12,000 , and public supply and domestic water use increased by about 2,000 acre-ft (fig. 3). This decrease in total water use was attributed primarily to agricultural fields removed from production in Pahrump Valley where irrigated acreage decreased from about 3,100 acres in 1998 to 2,400 acres in 1999 to 1,600 acres in 2000. By 2003, 1,700 acres had been converted from agriculture to residential land use. The maximum ground-water withdrawal in Pahrump Valley occurred during 1968 when 8,100 acres of cotton and alfalfa were irrigated with 46,000 acre-ft.

Total ground-water withdrawal from Amargosa Desert decreased from 1998 (21,100 acre-ft) to 2001 (14,100 acre-ft), and then increased through 2003 (17,600 acre-ft). Total ground-water withdrawal averaged 16,800 acre-ft from 1994 through 2003 and ranged from 14,100 to 21,100 acre-ft. The annual variation in total ground-water withdrawal is attributed primarily to crop and irrigation cycles (fig. 3 ). Alfalfa fields typically are fallowed 2 years during a 7 -year period. Other fields are irrigated once every 5 years to demonstrate beneficial use and maintain water rights.

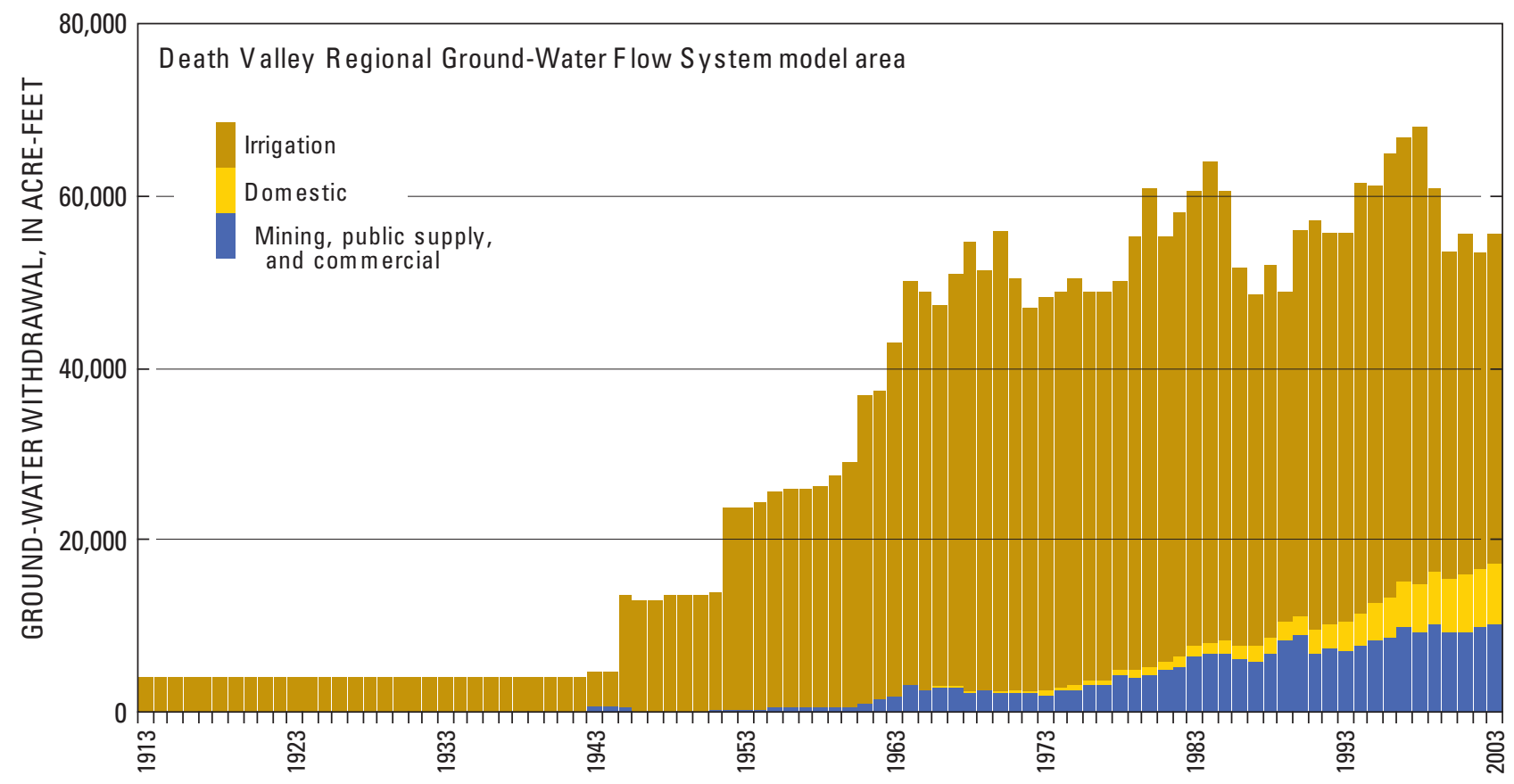

Figure 2. Total ground-water withdrawals by water-use class in the Death Valley regional ground-water flow system model area, Nevada and California, 1913-2003. 


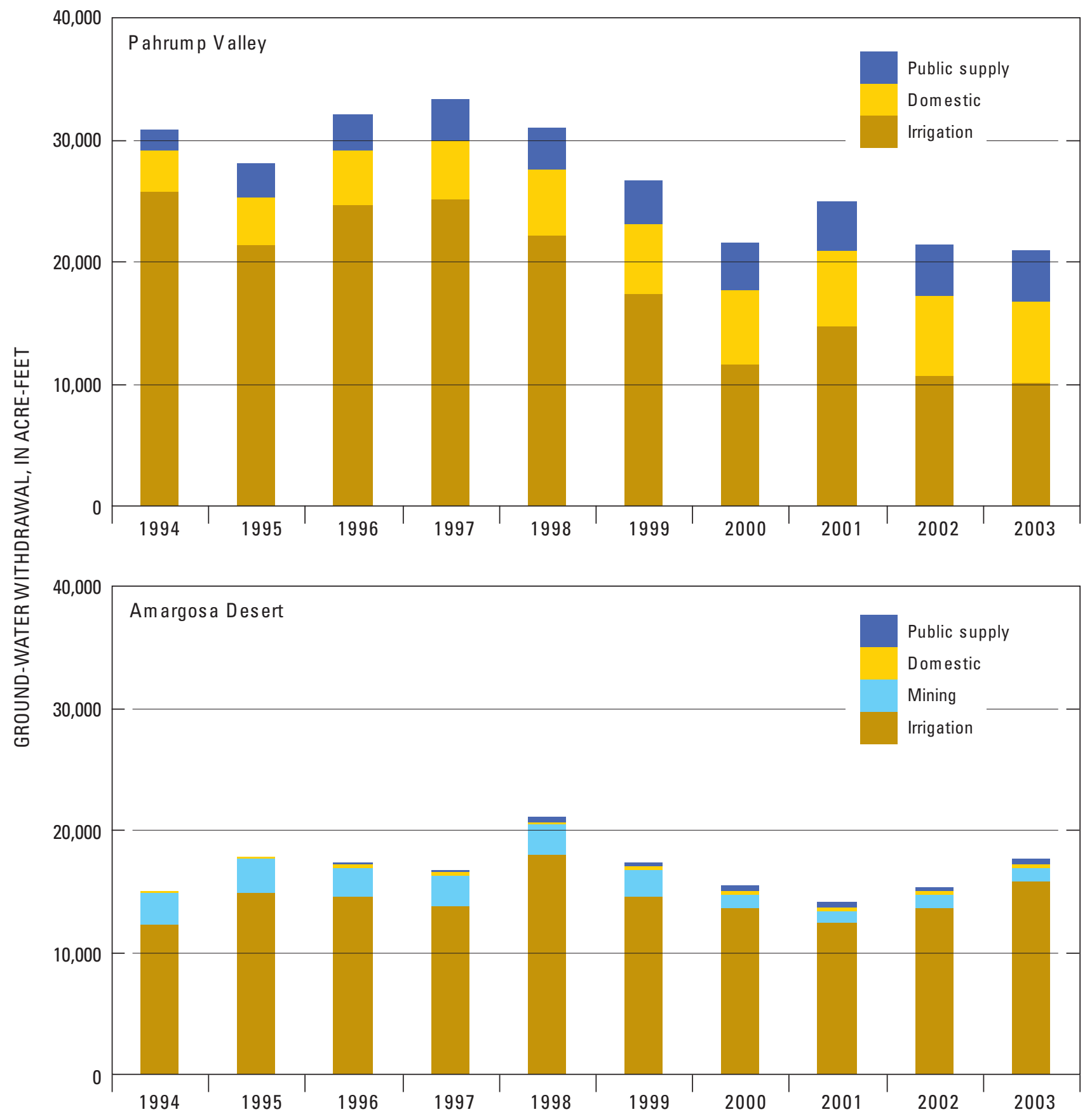

Figure 3. Ground-water withdrawals for significant water-use classes for selected hydrographic areas and Nevada Test Site, Death Valley regional ground-water flow system, Nevada and California, 1994-2003. 


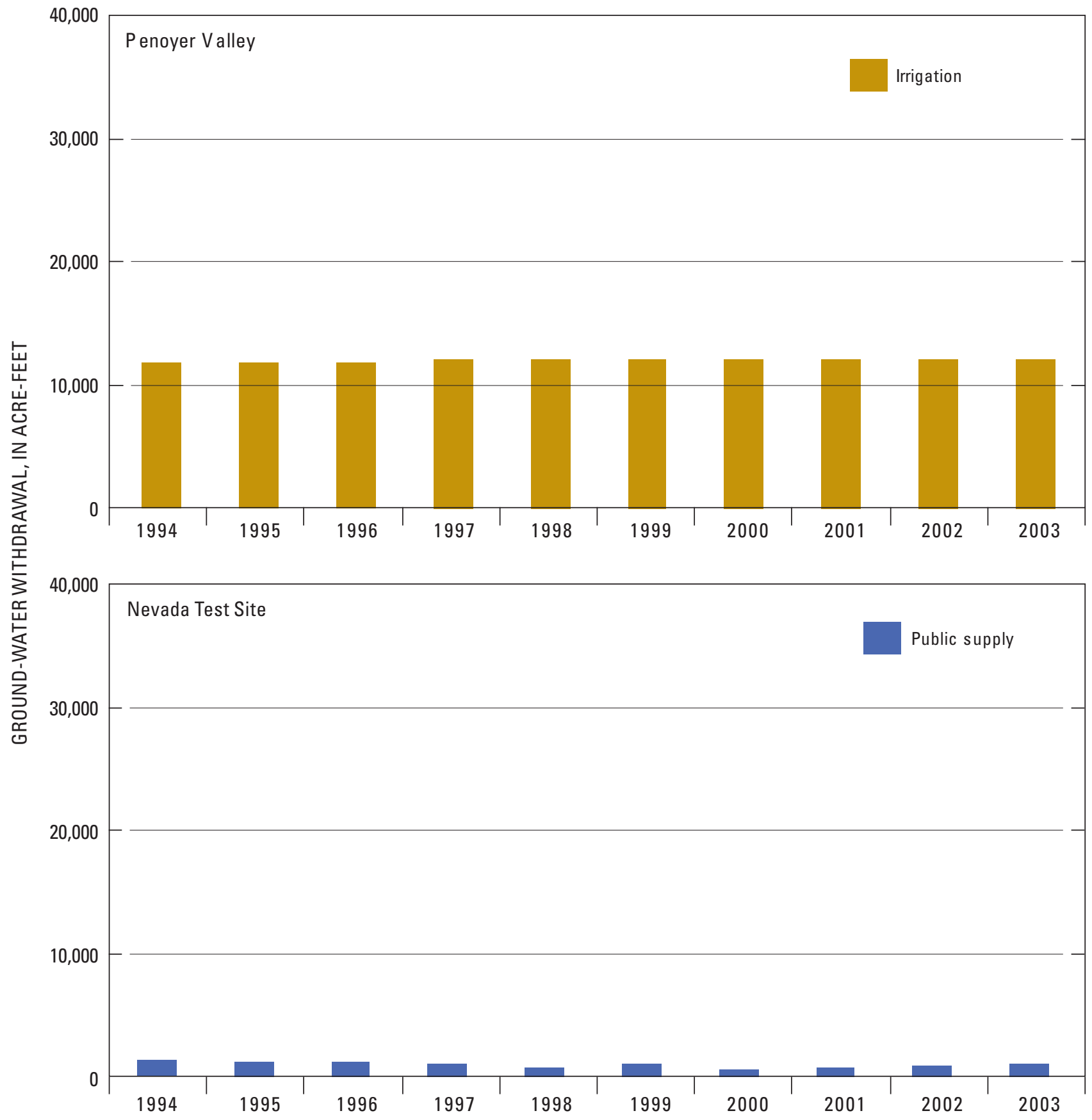

Figure 3.-Continued 
In 2003, 12 percent of reported irrigated acreage for Amargosa Desert was metered, including two of the larger fields, 125 and 112 acres. Application rates for these two fields were about 5 and $6 \mathrm{ft}$, respectively. These rates were on the low end of 5 to $9 \mathrm{ft} / \mathrm{yr}$ range estimated for the Amargosa Desert (table 1). It is unclear whether these application rates are representative of application rates in other fields that are not metered.

Ground-water withdrawals for nonirrigation use in Amargosa Desert ranged from 11 to 16 percent of total ground-water withdrawals between 1998 and 2003. Groundwater use for mining decreased from 2,400 acre-ft (11 percent of total water use) in 1998 to 1,200 acre-ft (7 percent of total water use) in 2003 because of the closure of the Bullfrog Mine owned by Barrick Gold Corporation. Domestic and public supply water use from 1998 to 2003 was less than 5 percent of the total water use.

Other significant areas of ground-water withdrawal are Penoyer Valley and NTS (fig. 3). Irrigation is the only major water use in Penoyer Valley, and did not change from 1998 to 2003 (about 12,600 acre-ft). Ground-water withdrawals supporting NTS activities ranged from about 670 acre-ft to 1,040 acre-ft between 1998 and 2003.

\section{Acknowledgments}

The authors wish to thank the cooperating agencies for funding this work and local farmers for providing valuable insights. We also thank the Nevada Division of Water Resources and numerous Federal, utility, and mining personnel for providing the data included in this report, and Randell Laczniak of the U.S. Geological Survey for acquiring these data and general guidance.

\section{References Cited}

Allen, R.G., Walter, I.A., Elliott, R.L., Howell, T.A., eds., 2005, The ASCE standardized reference evapotranspiration equation: American Society of Civil Engineers, 216 p.

Belcher, W.R., D’Agnese, F.A., and O'Brien, G.M., 2004, A. Introduction, in Belcher, W.R., ed., Death Valley regional ground-water flow system, Nevada and CaliforniaHydrogeologic framework and transient ground-water flow model: U.S. Geological Survey Scientific Investigations Report 2004-5205, p. 3-19, online at http://pubs.usgs.gov/sir/2004/5205/

Flint, L.E., and Flint, A.L., 2007, Regional analysis of groundwater recharge, in Stonestrom, D.A., Constantz, J., Ferré, T.P.A., and Leake, S.A., eds., Ground-water recharge in the arid and semiarid southwestern United States: U.S. Geological Survey Professional Paper 1703, p. 29-59, online at http://pubs.usgs.gov/pp/pp1703/b/

Moreo, M.T., Halford, K.J., La Camera, R.J., and Laczniak, R.J., 2003, Estimated ground-water withdrawals from the Death Valley regional flow system, Nevada and California, 1913-98: U.S. Geological Survey Water-Resources Investigations Report 03-4245, 28 p., on-line at http://pubs.usgs.gov/wri/wrir034245/

San Juan, C.A., Belcher, W.R., Laczniak, R.J., and Putnam, H.M., 2004, C. Hydrologic components for model development, in Belcher, W.R., ed., Death Valley regional ground-water flow system, Nevada and CaliforniaHydrogeologic framework and transient ground-water flow model: U.S. Geological Survey Scientific Investigations Report 2004-5205, p. 99-136, on-line at http://water.usgs.gov/pubs/sir/2004/5205/

Shevenell, Lisa, 1996, Statewide potential evapotranspiration maps for Nevada: Nevada Bureau of Mines and Geology, report $48,32 \mathrm{p}$.

U.S. Department of Agriculture, 1993, National Engineering Handbook, part 623, chapter 2, Irrigation Water Requirements Guide: Soil Conservation Service, 304 p. 
8 Update to the Ground-Water Withdrawals Database, Death Valley Regional Ground-Water Flow System, Nev.-Calif., 1913-2003

This page intentionally left blank. 


\section{Appendix A. Ground-Water Withdrawal Data for the Death Valley Regional Ground-Water Flow System, 1913-2003}

The database distributed with this report is in Microsoft ${ }^{\circledR}$ Access 2000 format. Table names are prefixed with "tbl_" and queries with "qry_". Table, query, and column headings are described in table A1. The location of withdrawal points used for public supply have been omitted and replaced with "99999" pursuant to directives issued by the Department of Homeland Security.

Table A1. Description of Microsoft ${ }^{\circledR}$ Access database for ground-water withdrawal data, Death Valley regional ground-water flow system, Nevada and California, 1913-2003.

[Table/query/column headings: Table names preceded by tbl_; query names preceded by qry_]

Table/Query/Column Headings

\begin{tabular}{ll}
\hline \multicolumn{1}{c}{ Tables } & \multicolumn{1}{c}{ Description } \\
\hline tbl_application rates & Rates applied to irrigation and domestic uses \\
tbl_raw_data & Raw annual data \\
tbl_spatial & Location and depths of withdrawal points \\
tbl_withdrawals & Withdrawals summed by withdrawal point and year \\
\hline \multicolumn{1}{c}{ Queries } & \multicolumn{1}{c}{ Description } \\
\hline
\end{tabular}

qry_domestic_withdrawals_ha

qry_domesic_withdrawals_withdrawal point

qry_irrigation_withdrawals_ha

qry_irrigation_withdrawals_record

qry_irrigation_withdrawals_withdrawal point

qry_other_withdrawals_ha

qry_other_withdrawals_record

qry_other_withdrawals_withdrawal point

\begin{tabular}{|c|c|}
\hline Column & Description \\
\hline acres_irrigated & Number of acres irrigated \\
\hline altitude & Withdrawal point altitude, in feet above mean sea level \\
\hline application_rate_best & Best estimate application rate (foot per year) \\
\hline application_rate_max & Maximum estimated application rate (foot per year) \\
\hline application_rate_min & Minimum estimated application rate (foot per year) \\
\hline bottom_completion & Lower end of interval in which ground water is withdrawn, in feet below land surface \\
\hline bottom_max_completion & $\begin{array}{l}\text { Maximum lower end of interval in which ground water is withdrawn, in feet below land } \\
\text { surface }\end{array}$ \\
\hline crop_type & $\begin{array}{l}\mathrm{L}=\text { low water-use crops; } \mathrm{H}=\text { high water-use crops; } \mathrm{M}=\text { undifferentiated crop types; } \mathrm{X}=\text { not } \\
\text { applicable }\end{array}$ \\
\hline east_utm & Easting of withdrawal point, in meters \\
\hline error_coefficient & $\begin{array}{l}-4=\text { no use extrapolated; }-3=\text { no use interpolated; }-2,-1,0=\text { no use reported or interpreted; } \\
1,2=\text { withdrawal reported or interpreted; } 3=\text { withdrawal interpolated; } 4=\text { withdrawal } \\
\text { extrapolated; } 5=\text { withdrawal metered }\end{array}$ \\
\hline ha & Hydrographic area designator \\
\hline ha_plss_id & Hydrographic area, township, range, section \\
\hline latitude & Latitude of withdrawal point, in decimal degrees \\
\hline longitude & Longitude of withdrawal point, in decimal degrees \\
\hline north_utm & Northing of withdrawal point, in meters \\
\hline remarks & Point of withdrawal description \\
\hline top_completion & Upper end of interval in which ground water is withdrawn, in feet below land surface \\
\hline top_min_completion & $\begin{array}{l}\text { Minimum upper end of interval in which ground water is withdrawn, in feet below land } \\
\text { surface }\end{array}$ \\
\hline withdrawal_best & Best withdrawal estimate, in acre-feet \\
\hline
\end{tabular}

Domestic withdrawals summed by hydrographic area and year

Domestic withdrawals summed by withdrawal point and year

Irrigation withdrawals and irrigated acres summed by hydrographic area and year

Irrigation withdrawals summed by record

Irrigation withdrawals and irrigated acres summed by withdrawal point and year

All withdrawals other than irrigation and domestic summed by hydrographic area and year

All withdrawals other than irrigation and domestic summed by record

All withdrawals other than irrigation and domestic summed by withdrawal point and year

\section{Number of acres irrigated}

Maximum estimated application rate (foot per year)

Maximum lower end of interval in which ground water is withdrawn, in feet below land

applicable

Easting of withdrawal point, in meters

1,2=withdrawal reported or interpreted; $3=$ withdrawal interpolated; 4=withdrawal

topolated; $5=$ withdrawal metere

Hydrographic area, township, range, section

Latitude of withdrawal point, in decimal degrees

Point of withdrawal description

Minimum upper end of interval in which ground water is withdrawn, in feet below land

Best withdrawal estimate, in acre-feet 
Table A1. Description of Microsoft ${ }^{\circledR}$ Access database for ground-water withdrawal data, Death Valley regional ground-water flow system, Nevada and California, 1913-2003.-Continued

[Table/query/column headings: Table names preceded by tbl_; query names preceded by qry_]

Table/Query/Column Headings

\section{Column}

withdrawal_coefficient

withdrawal_max

withdrawal_min

withdrawal_point

withdrawal_point_accuracy

wtr_use

year

\section{Description}

Irrigation use $=$ number of acres irrigated, domestic use $=$ number of wells, all other water uses $=$ amount of withdrawal, in acre-feet per year

Maximum withdrawal estimate, in acre-feet

Minimum withdrawal estimate, in acre-feet

Point of withdrawal designator

Accuracy of latitude/longitude placement of withdrawal point, in feet

Water use; $\mathrm{C}=$ commercial; $\mathrm{H}=$ domestic; $\mathrm{I}=$ irrigation; $\mathrm{K}=$ mining; $\mathrm{N}=$ industrial; $\mathrm{P}=$ public supply; R=recreation; $\mathrm{S}=$ stock; $\mathrm{W}=$ wildlife; $\mathrm{Z}=$ other

Calendar year of withdrawal 
For more information contact:

Director, Nevada Water Science Center

U.S. Geological Survey

2730 N. Deer Run Road

Carson City, Nevada 89701

http://nevada.usgs.gov 


\section{애용}

궁

产

움

들

훟

옹

言

邑

产

ग

흥.

a

递

2

方 